\title{
ANALISIS REAKSI PASAR MODAL TERHADAP PERISTIWA PEMILU SERENTAK TAHUN 2019
}

\author{
Desak Ruric Pradnya Paramitha Nida (ruricpradnya@ymail.com) \\ I Gusti Agung Prama Yoga (pramayoga13@gmail.com) \\ I Made Gandhi Adityawarman (gandhiaditya@gmail.com) \\ Universitas Warmadewa
}

\begin{abstract}
ABSTRAK
Penelitian ini merupakan studi peristiwa yang bertujuan untuk menguji secara empiris perbedaan abnormal return dan volume perdagangan saham yang diperoleh investor di Bursa Efek Indonesia sebelum dan setelah Peristiwa Pemilu Serentak Tahun 2019 dengan variabel abnormal return dan trading volume activity. Penentuan sampel menggunakan metode sampel jenuh dengan sampel sebanyak 45 perusahaan anggota Indeks LQ45 periode Februari-Juli 2019. Penelitian ini menggunakan data sekunder berupa harga penutupan saham harian, volume perdagangan saham harian, dan jumlah saham yang beredar selama periode penelitian. Periode peristiwa dalam penelitian ini adalah 11 hari perdagangan saham yang terdiri dari 5 hari sebelum $(\mathrm{t}-5)$, hari saat peristiwa $(\mathrm{t}=0)$ dan 5 hari sesudah $(t+5)$ Pemilu Serentak Tahun 2019. Pengujian terhadap hipotesis menggunakan Paired Sample T-Test dan Wilcoxon Signed Ranks Test. Hasil penelitian menunjukkan bahwa tidak terdapat perbedaan signifikan rata-rata abnormal return antara sebelum dan sesudah peristiwa dan tidak terdapat perbedaan signifikan rata-rata trading volume activity antara sebelum dan sesudah peristiwa Pemilu Serentak Tahun 2019. Dengan demikian peristiwa Pemilu Serentak Tahun 2019 tidak memiliki kandungan informasi yang menyebabkan pasar modal tidak bereaksi.
\end{abstract}

Kata Kunci: Studi Peristiwa, Abnormal Return, Trading Volume Activity, Pemilu Serentak 2019.

\section{PENDAHULUAN}

Pasar modal merupakan suatu tempat yang mempertemukan pembeli dan penjual efek dengan risiko berupa laba dan rugi. Pasar modal bisa menjadi sarana perusahaan dalam meningkatkan kebutuhan akan dana jangka panjang dengan cara menawarkan saham atau obligasi (Hartono, 2017:29). Pasar modal menurut UU No. 8 Tahun 1995 pasal 1 ayat 13 adalah suatu pasar yang mempunyai kegiatan melakukan penawaran umum dan perdagangan efek, perusahaan publik yang berkaitan dengan efek yang diterbitkannya, serta lembaga dan profesi yang berkaitan dengan efek.

Berbagai peristiwa yang terjadi di suatu wilayah atau negara, baik itu berupa peristiwa ekonomi maupun non ekonomi, pada dasarnya mengandung informasi berharga yang tidak bisa lepas dari pasar modal. Salah satu peristiwa non ekonomi yang bisa sangat berpengaruh terhadapfluktuasi harga saham di pasar modal adalah peristiwa politik. Kondisi politik suatu negara yang stabil dan tenang cenderung meningkatkan kinerja ekonomi negara tersebut. Hal ini dikarenakan rendahnya risiko kerugian yang mungkin diakibatkan oleh faktor politik tersebut.

Salah satu peristiwa politik yang cukup bersejarah dan berskala nasional yang terjadi di Indonesia adalah gelaran pesta demokrasi Pemilu Serentak Tahun 2019 yang dilaksanakan pada hari Rabu, 17 April 2019. Saat itu digelar pemilu serentak yang menggabungkan Pilpres dan Pileg untuk pertama kalinya dalam satu hari. Pasar modal 
bisa bereaksi terhadap peristiwa tersebut jika peristiwa tersebut memiliki kandungan informasi.

Studi peristiwa atau event study dapat digunakan untuk menguji kandungan informasi pada suatu peristiwa. Pengujian kandungan informasi ini dimaksudkan untuk melihat reaksi pasar terhadap suatu peristiwa. Jika peristiwa memiliki kandungan informasi, maka diharapkan pasar akan bereaksi saat berita mengenai suatu peristiwa tersebut diterima oleh pasar. Reaksi ini diukur menggunakan variable abnormal return dan vlume perdagangan saham. Sebaliknya, peristiwa yang tidak mengandung informasi tidak akan memberikan abnormal return kepada investor.

Penelitian ini memiliki tujuan untuk mengetahui perbedaan rata-rata Abnormal Return(AR) dan rata-rata Volume Perdagangan Saham (Trading Volume Activity/ATVA) antara sebelum dan sesudah peristiwa Pemilu Serentak Tahun 2019.

\section{TINJAUAN PUSTAKA}

\section{Teori Sinyal}

Teori sinyal (signaling theory) merupakan teori yang membahas mengenai naik turunnya harga saham, oblihasi, dan yang lainnya di pasar, sehingga akan memberikan pengaruh pada keputusan investor (Fahmi, 2014). Teori sinyal memiliki kaitan dengan informasi yang digunakan sebagai sinyal bagi para investor.Suatu peristiwa yang memiliki kandungan informasi bisa menjadi sinyal bagi para investor untuk menentukan keputusan investasi mereka di pasar modal.

Tanggapan dari para investor di pasar modal terhadap sinyal positif dan negatif akan sangat mempengaruhi kondisi pasar, investor akan bereaksi dengan berbagai cara dalam menanggapi sinyal tersebut, seperti membeli dan menjual saham, atau mungkin tidak bereaksi.

\section{Teori Efisiensi Pasar}

Pasar modal bisa dikatakan baik jika pasar modal terebut efisien. Pasar efisien merupakan kondisidi mana pasar bisa melakukan penyesuaian harga menuju keseimbangan atau ekuilibrium yang baru dalam waktu yang cepat (Hartono, 2018:15).Suatu pasar bisa dikatakan efisien apabila tidak ada seorang pun, baik itu investor individu maupun investor institusi mampu memperoleh imbal hasil atau return yang tidak normal, setelah disesuaikan dengan risiko, serta dengan memakai strategi perdagangan yang ada.

\section{Studi Peristiwa}

Studi peristiwa (event study) banyak digunakan dalam menguji reaksi pasar terhadap suatu peristiwa, kejadian, atau pengumuman. Studi peristiwa merupakan sebuah studi yang mempelajari reaksi pasar terhadap suatu peristiwa yang informasinya dipublikasikan sebagai suatu pengumuman (Hartono, 2017:643).

Studi peristiwa dilakukan dengan tujuan untuk mengetahui reaksi pasar terhadap suatu peristiwa atau pengumuman yang memiliki kandungan informasi.Suatu peristiwa akan dianggap sebagai kabar baik atau kabar buruk tergantung dari nilai ekonomis yang dimiliki.

\section{Pasar Modal}

Pasar modal (capital market) merupakan suatu tempat di mana berbagai pihak seperti perusahaan yang menjual saham dan obligasi dengan tujuan hasil penjualannya akan digunakan sebagai tambahan dana atau memperkuat modal perusahaan (Fahmi, 2014:305).Pasar modal bisa menjadi sarana efektif untuk membentuk modal serta alokasi dana yang bertujuan untuk meningkatkan keterlibatan masyarakat banyak guna menunjang pembangunan dan pembiayaan nasional untuk mendorong pertumbuhan ekonomi negara dan meningkatkan kesejahteraan masyarakat luas. 


\section{Saham}

Saham merupakan suatu tanda bukti penyertaan kepemilikan modal atau dana pada suatu perusahaan yang bisa berupa kertas yang di dalamnya tercantum dengan jelas nilai nominal, nama perusahaan, dan diikuti juga dengan hak serta kewajiban yang dijelaskan kepada setiap pemegangnya (Fahmi, 2014:323).Sebagai salah satu instrumen dari pasar modal, saham cukup populer di mata investor karena bisa memberi tingkat keuntungan yang menarik.

\section{Indeks LQ45}

Indeks LQ45 dimulai pada tanggal 13 Juli 1994 dan tanggal ini menjadi hari dasar indeks dengan nilai awal 100. Indeks LQ45 adalah indeks likuiditas empat puluh lima perusahaan yang selama ini dianggap mempunyai kinerja yang bisa dipertanggung jawabkan serta memenuhi kriteria yang telah dipersyaratkan oleh otoritas bursa.Pertimbangan-pertimbangan pemilihan saham yang masuk anggota indeks LQ45 adalah likuiditas dan kapitalisasi pasar yang besar.

\section{Pengembalian Saham}

Pengembalian saham (stock return)merupakan imbal hasil atauincome yang bisa didapat oleh investor atas hasil investasi yang dilakukan pada suatu sekuritas. Pengembaliansaham bisa dibedakan menjadi dua jenis (Hartono, 2017:283), yaitu return realisasian (realized return) dan juga return ekspektasian (expected return). Return realisasian merupakan return masa lampau yang sudah terjadi. Return realisasian dikalkulasikan menggunakan data historis.Return realisasian menjadi penting karena bisa digunakan menjadi alatukur kinerja dari suatu perusahaan dansebagai dasar penentuan return ekspektasian serta risiko di masa yang mendatang.

\section{Pemilu Serentak Tahun 2019}

Pemilihan umum serentak tahun 2019 adalah peristiwa yang bersejarah bagi Indonesia karena merupakan pemilu serentak pertama yang menggabungkan lima jenis pemilihan sekaligus, yaitu pemilihan DPRD Kabupaten/kota, DPRD Provinsi, DPR, DPD, Presiden dan Wakil Presiden dalam sekali waktu.Gagasan dan ide pemilu serentak sendiri tidak muncul begitu saja sebelum pelaksanaan Pemilu 2019. Ide tersebut dimulai justru sebelum Pemilu 2014 yang lalu ketika seorang akademisi Effendi Ghazali bersama Koalisi Masyarakat untuk Pemilu Serentak mengajukan uji materi UU Nomor 42 tahun 2008 tentang Pemilu ke MK (Mahkamah Konstitusi) pada tahun 2013 yang lalu. (www.cnnindonesia.com).

\section{Abnormal Return}

Abnormal return atau excess return merupakan suatu kelebihan dari return sesungguhnya terjadi terhadap return normal. (Hartono, 2017:667). Maka dengan demikian pengembalian abnormal merupakan selisih antara return yang diharapkan dengan return yang didapatkan.

Jika selisih return yang didapatkan lebih besar dari return yang diharapakan atau return yang dihitung maka akan disebut return positif, begitu juga sebaliknya. Abnormal return bisa terjadi dikarenakan terdapat suatu peristiwa atau pengumuman tertentu, misalnya pengumuman pembagian dividen, stock split, cuti bersama, suasana politik yang tidak stabil, kejadian-kejadian luar biasa, IPO, dan lain sebagainya.

\section{Volume Perdagangan Saham}

Volume perdagangan saham adalah suatu instrumen yang bisa digunakan untuk melihat reaksi pasar modal terhadap informasi dengan menggunakan parameter berupa pergerakan aktivitas volume perdagangan saham di pasar modal. Volume perdagangan saham atau trading volume activity merupakan 
keseluruhan nilai transaksi pembelian maupun penjualan saham yang dilakukan oleh investor dalam satuan uang.

Volume perdagangan saham atau trading volume activitybisa mencerminkan dan menunjukkan seberapa aktif dan liquid suatu saham diperdagangkan di pasar modal. Aktivitas volume perdagangan bisa dipakai sebagai acuan untuk menentukan apakah seorang investor individu memandang suatu peristiwa itu bermanfaat atau tidak.

\section{Kerangka Pemikiran}

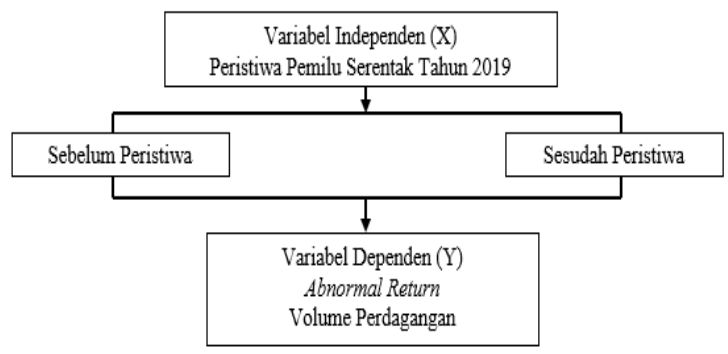

Hipotesis yang digunakan dalam penelitian ini adalah sebagai berikut:

1. Terdapat perbedaan average abnormal return sebelum dan setelah peristiwa Pemilu Serentak Tahun 2019.

2. Terdapat perbedaan rata-rata volume perdagangan saham sebelum dan setelah peristiwa Pemilu Serentak Tahun 2019.

\section{METODE PENELITIAN}

\section{Populasi dan Metode Penentuan Sampel}

Populasi pada penelitian ini adalah seluruh perusahaan yang termasuk ke dalam indeks LQ45 di Bursa Efek Indonesia. Metode pengambilan sampel pada penelitian ini menggunakan metode sampel jenuh, yaitu menggunakan keseluruhan populasi sebagai sampel penelitian. Alasan dipilihnya indeks LQ45 karena merupakan indeks yang beranggotakan perusahaan berkapitalisasi pasar dengan nilai perdagangan terbesar di
BEI sehingga diharapkan mampu mencerminkan kondisi IHSG secara keseluruhan.

\section{Variabel Penelitian}

Variabel dependen pada penelitian ini adalah Abnormal Return dan Volume Perdagangan Saham, sedangkan variabel independen pada penelitian ini adalah peristiwa Pemilu Serentak Tahun 2019.

\section{Definisi Operasional Variabel}

\section{Abnormal Return}

Abnormal return atau excess return merupakan kelebihan dari return yang sesungguhnya terjadi terhadap return normal. (Hartono, 2017:668).

$$
\mathrm{RTN}_{\mathrm{i}, \mathrm{t}}=\mathrm{R}_{\mathrm{i}, \mathrm{t}}-\mathrm{E}\left[\mathrm{R}_{\mathrm{i}, \mathrm{t}}\right]
$$

2. Return sesungguhnya (actual return)

Return sesungguhnya atau return realisasian (realized return) adalah return yang terjadi pada waktu ke-t yang merupakan selisih dari harga sekarang relatif terhadap harga sebelumnya. (Hartono, 2017:284)

$$
\mathrm{R}_{\mathrm{i}, \mathrm{t}}=\frac{\mathrm{P}_{\mathrm{i}, \mathrm{t}}-\mathrm{P}_{\mathrm{i}, \mathrm{t}-1}}{\mathrm{P}_{\mathrm{i}, \mathrm{t}-1}}
$$

3. Return ekspektasian (expected return)

Return ekspektasian atau expected return adalah return atau pengembalian yang diharapkan oleh investor akan diperoleh di masa mendatang. Pada penelitian ini digunakan model disesuaikan pasar (market-adjusted model)(Hartono, 2018:76).

$$
\mathrm{E}\left[\mathrm{R}_{\mathrm{i}, \mathrm{t}}\right]=\mathrm{R}_{\mathrm{mt}}
$$

4. Return pasar model disesuaikan pasar (market-adjusted model)

Return pasar merupakan tingkat keuntungan pasar yang dalam penelitian ini menggunakan indeks LQ45. (Hartono, 2018:76).

$$
\mathrm{R}_{\mathrm{mt}}=\frac{\text { Indeks LQ45 }_{\mathrm{t}}-\text { Indeks LQ45 } \mathrm{t}-1}{\text { Indeks LQ45 }}
$$


5. Rata-rata abnormal return (average abnormal return/AAR)

Menghitung average abnormal return untuk seluruh saham per hari selama periode peristiwa(Hartono, 2018:96).

$$
\operatorname{RRTN}_{\mathrm{t}}=\frac{\sum_{\mathrm{i}=1}^{\mathrm{k}} \mathrm{RTN}_{\mathrm{it}}}{\mathrm{n}}
$$

6. Aktivitas Volume Perdagangan Saham (Trading Volume Activity)

Perhitungan TVA dilakukan dengan membandingkan jumlah saham perusahaan yang diperdagangkan dengan keseluruhan jumlah saham beredar di periode yang sama.

\section{TVA $=\frac{\sum \text { saham perusahaan } i \text { yang ditransaksikan pada hari ket }}{\sum \text { saham perusahaan i yang beredar pada hari ke t }}$}

7. Rata-rata Aktivitas Volume Perdagangan Saham (Trading Volume Activity/ATVA)

Menghitung average trading volume activity (ATVA) seluruh saham per hari selama periode peristiwa.

$$
\operatorname{ATVA}_{\mathrm{t}}=\frac{\sum_{\mathrm{i}=1}^{\mathrm{n}} \mathrm{TVA}_{\mathrm{it}}}{\mathrm{n}}
$$

Periode kejadian dalam penelitian ini digunakan selama 11 hari, yaitu terdiri dari 5 hari sebelum peristiwa (pre-event), 1 hari saat peristiwa (event date), dan 5 hari setelah peristiwa (post-event). Periode selama 11 hari dilakukan guna menghindari efek pengganggu (confounding effect) dari kejadian lain yang mungkin mempengaruhi hasil penelitian jika periode pengamatan dipilih telalu lama.

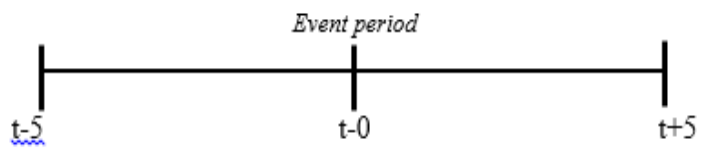

\section{Teknik Analisis Data}

1. Analisis Statistik Deskriptif

Statistik deskriptif berguna untuk memberikan deskripsi atau gambaran umum dari suatu data yang dilihat dari nilai rata-rata dan nilai standar deviasi.

2. Uji Normalitas
Pengujian normalitas dilakukan untuk mengetahui apakah variabel-variabel yang digunakan dalam penelitian ini terdistribusi dengan normal atau tidak. Uji normalitas dilakukan menggunakan uji KolmogorovSmirnov.

3. Uji Beda Rata-Rata

Uji beda rata-ratadigunakan untuk menjelaskan ada atau tidaknya perbedaan signifikan antara rata-rata Abnormal Return dan rata-rata Volume Perdagangan Saham. Jika data terdistribusi normal maka digunakan Uji Paired Sample T-test, jika tidak terdistribusi normal digunakan Uji Wilcoxon Signed Rank Test.

\section{HASIL ANALISIS DAN PEMBAHASAN}

\section{Analisis Statistik Deskriptif}

\section{Hasil Analisis Statistik Deskriptif}

Descriptive Statistics

\begin{tabular}{|l|r|r|r|r|r|}
\hline & \multicolumn{1}{|c|}{$\mathrm{N}$} & \multicolumn{1}{|c|}{ Minimum } & Maximum & \multicolumn{1}{c|}{ Mean } & Std. Deviation \\
\hline AAR SEBELUM & 45 & .019 & .018 & .00056 & .009057 \\
AAR SESUDAH & 45 & .025 & .039 & .00267 & .010323 \\
ATVA SEBELUM & 45 & .000 & .011 & .00178 & .002014 \\
ATVA SESUDAH & 45 & .000 & .015 & .00193 & .002653 \\
Valid N (listwise) & 45 & & & & \\
\hline
\end{tabular}

Sumber: Data diolah, 2020.

1. Rata-rata variabel average abnormal return (AAR) sebelum peristwa sebesar 0.0006 dengan standar deviasi sebesar 0.00906, nilai rata-rata variabel average abnormal return (AAR) sesudah peristiwa sebesar 0.0027 dengan standar deviasi sebesar 0.01032 .

2. Nilai rata-rata average trading volume activity (ATVA) sebelum peristwa sebesar 0.0018 dengan standar deviasi sebesar 0.00201 , nilai rata-rata average trading volume activity (ATVA) sesudah peristwa sebesar 0.0019 dengan standar deviasi sebesar 0.00265 , nilai rata-rata harga saham sebelum peristwa sebesar 8236.80 dengan standar deviasi sebesar 14183.399, nilai rata-rata harga saham sesudah peristwa 
sebesar 8227.53 dengan standar deviasi sebesar 14240.960 .

\section{Uji Normalitas}

Uji normalitas dilakukan menggunakan uji Kolmogorov-Smirnov. Dengan tingkat signifikansi 0,05 maka jika angka signifikansi uji Kolmogorov smirnov Sig > 0,05 data terdistribusi normal, jika angka signifikansi uji Kolmogorov smirnov Sig. $<0,05$ data tidak distribusi normal.

1. Uji Normalitas variabel Rata-Rata Abnormal Return

\section{Hasil Uji Normalitas Average Trading Volume Activity}
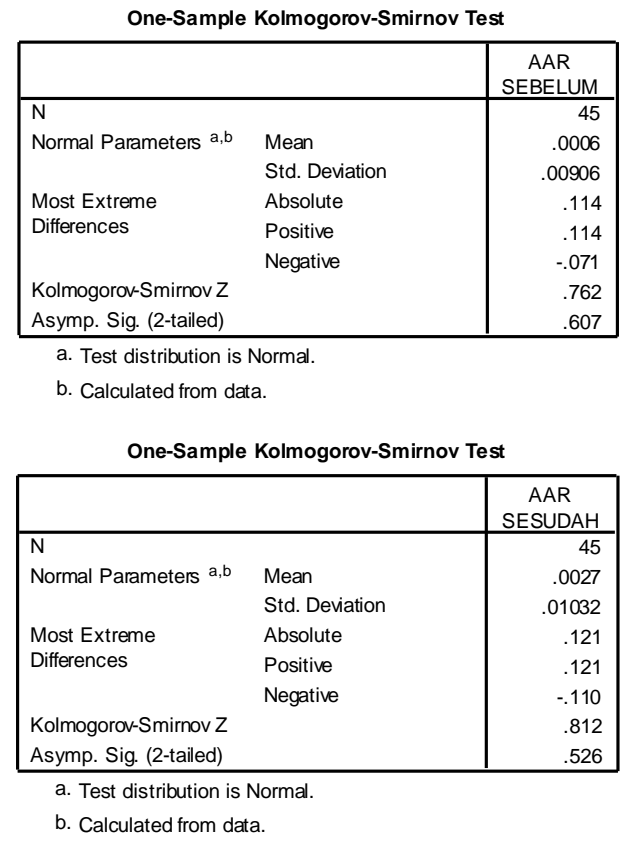

Sumber: Data diolah, 2020.

Hasil uji normalitas terhadap AAR sebelum dan sesudah peristiwa menunjukkan bahwa nilai Asymp. Sig. (2tailed) > Level Of Sifnifican(0,05), maka variabel AAR sebelum dan sesudah peristiwa berdistribusi normal, sehingga analisisnya dilanjutkan dengan Uji Paired Sample T-Test.

2. Uji Normalitas variabel Rata-Rata Volume Perdagangan Saham
Hasil Uji Normalitas Average Trading Volume Activity
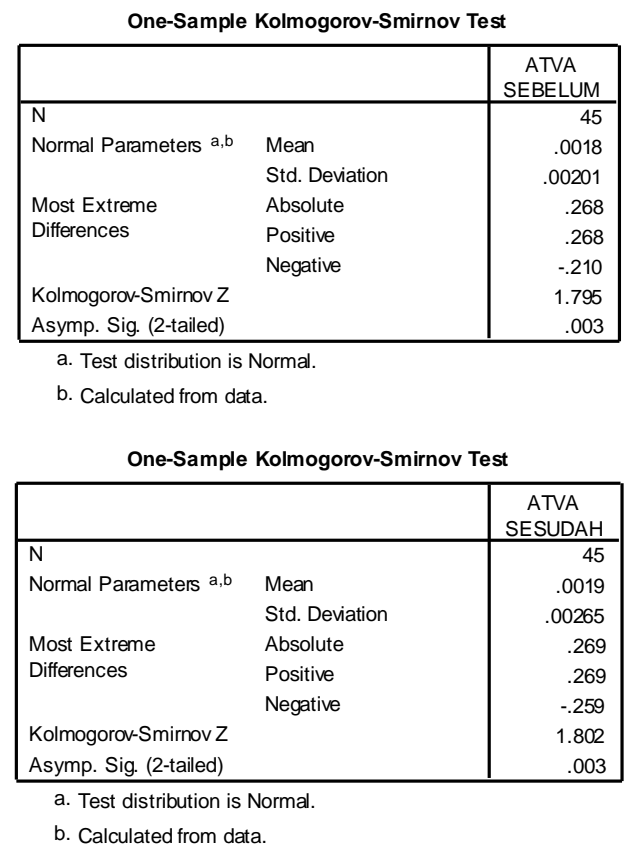

Sumber: Data diolah, 2020.

Hasil uji normalitas terhadap ATVA sebelum dan sesudahperistiwa menunjukkan bahwa nilai Asymp. Sig. (2-tailed) > Level Of Sifnifican (0,05), maka variabel AAR sebelum dan sesudah peristiwa tidak berdistribusi normal, sehingga analisisnya dilanjutkan dengan Uji Wilcoxon Signed Ranks Test.

\section{Uji Hipotesis}

Setelah dilakukan Uji Normalitas, Pengujian hipotesis selanjutnya dilakukan dengan teknik Uji Beda Rata-Rata. Untuk variabel AAR dilakukan dengan Uji Paired Sample T-Testdan variabel ATVA dilakukan dengan Uji Wilcoxon Signed Ranks Test.

1. Hipotesis I

Terdapat perbedaan average abnormal return sebelum dan setelah peristiwa Pemilu Serentak Tahun 2019. 


\section{Hasil UjiPaired Sample T-Test Variabel Average Abnormal Return}

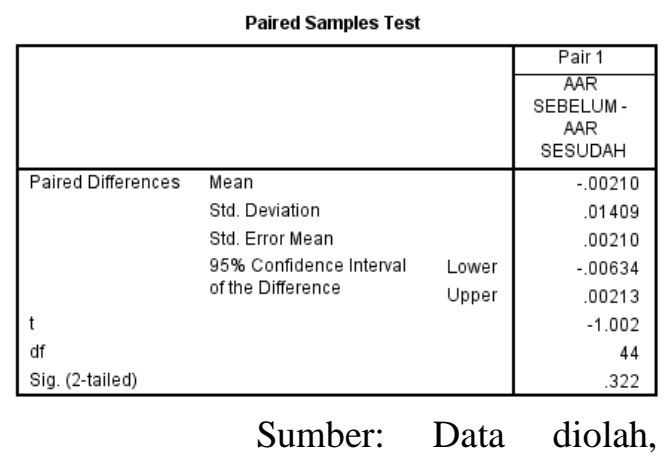

2020

Uji paired sample t-testpada tabel di atas memperlihatkan hasil nilai $\mathrm{t}$ atau $t$ value sebesar $|-1.002|$ dengan signifikansi (sig) sebesar 0.322 . Dikarenakan taraf signifikansi sebesar $0.322>0.05$, inferensi yang diambil adalah menolak Hipotesis I dan bisa disimpulkan bahwa tidak terdapat perbedaan averageabnormal return yang signifikan antara sebelum dan sesudah peristiwa Pemilu Serentak Tahun 2019.

2. Hipotesis II

Terdapat perbedaan rata-rata volume perdagangan saham sebelum dan setelah peristiwa Pemilu Serentak Tahun 2019.

\section{Hasil Uji Wilcoxon Signed Ranks Test Variabel Rata-Rata Volume Perdagangan Saham Test Statistics ${ }^{b}$}

\begin{tabular}{|l|c|}
\hline & ATVA \\
& SESUDAH - \\
& ATVA \\
& SEBELUM \\
\hline$Z$ & $-.040^{\mathrm{a}}$ \\
Asymp. Sig. (2-tailed) & .968 \\
\hline
\end{tabular}

a. Based on positive ranks.

b. Wilcoxon Signed Ranks Test

Sumber: Data diolah, 2020

Uji Wilcoxon Signed Ranks pada tabel di atas memperlihatkan hasil Asymp. Sig (2-tailed) sebesar $0.968>0.05$ yang berarti nilai Asymp. Sig, (2-tailed) lebih besar dari 0.05 maka inferensi yang diambil adalah menolakHipotesis II, artinya tidak terdapat perbedaan rata-rata yang signifikan pada volume perdagangan saham sebelum dan setelah peritiwa Pemilu Serentak Tahun 2019.

\section{SIMPULAN}

Berdasarkan pada analisis data yang telah dilakukan sebelumnya, maka bisa ditarik simpulan sebagai berikut

1. Hasil dari analisis data pada variabel average abnormal return (AAR) menunjukkan bahwa nilai signifikansi variabel AAR sebesar sebesar $0.322>0.05$, sehingga Hipotesis I ditolak dan bisa disimpulkan bahwa penelitian studi peristiwa pada Pemilu Serentak Tahun 2019 menunjukkan peristiwa Pemilu Serentak ini tidak memiliki cukup kandungan informasi yang menimbulkan reaksi dari pelaku pasar sehingga tidak terdapat perbedaan abnormal return yang signifikan antara sebelum dan setelah peristiwa Pemilu Serentak Tahun 2019. Para investor cenderung lebih memilih untuk menunggu hasil Pemilu Serentak resmi diumumkan sembari menantikan kebijakan ekonomi yang akan dibuat di kemudian hari.

2. Hasil dari analisis data pada variabel ratarata volume perdagangan saham menunjukkan bahwa nilai signifikansi variabel sebesar sebesar $0.968>0.05$, sehingga Hipotesis II ditolak dan bisa disimpulkan bahwa penelitian studi peristiwa pada Pemilu Serentak Tahun 2019 menunjukkan informasi yang terkandung dalam peristiwa Pemilu ini tidak memiliki cukup kandungan informasi sehingga tidak cukup untuk membuat pasar beraksi untuk melakukan transaksi di pasar modal yang menyebabkan tidak terdapat perbedaan volume perdagangan yang signifikan antara sebelum dan setelah 
peristiwa Pemilu Serentak Tahun 2019. Artinya investor tidak melakukan transaksi jual-beli saham secara signifikan selama masa Pemilu Serentak Tahun 2019 dan cenderung wait and see atau menunggu dan melihat situasi setelah Pemilu usai.

\section{SARAN}

Berdasarkan analisis penelitian yang sudah dibahas sebelumnya, maka terdapat beberapa saran yang bisa diberikan yaitu sebagai berikut:

1. Untuk penelitian selanjutnya diharapkan menambahkan sampel lain atau menggunakan indeks lain sehingga hasil penelitian akan menjadi lebih bervariasi.

2. Bagi peneliti selanjutnya yang ingin melakukan penelitian dengan tema yang serupa disarankan menambah variabel lain selain abnormal return dan volume perdagangan dan menggunakan periode pengamatan yang lebih panjang.

3. Untuk penelitian selanjutnya disarankan menggunakan peristiwa lain yang pengaruhnya lebih luas terhadap pasar modal seperti peristiwa regional dan internasional.

\section{DAFTAR PUSTAKA}

Aini Kolbiana. 2019. Analisis Pengaruh Peristiwa Terorisme di Surabaya Tahun 2018 Terhadap Abnormal Return dan Aktivitas Volume Perdagangan (Studi Empiris Pada Perusahaan Indeks LQ45 di Bursa Efek Indonesia). Skripsi. Jurusan Akuntansi Fakultas Ekonomi Dan Bisnis Universitas Lampung

Aryo Pamungkas, Suhadak, M.G Wi Endang N.P. 2015. Pengaruh Pemilu Presiden Indonesia Tahun 2014 Terhadap Abnormal Return dan Trading Volume
Activity (Studi Pada Perusahaan Pada Perusahaan Yang Tercatat Sebagai Anggota Indeks Kompas100). Jurnal Administrasi Bisnis (JAB)|Vol. 20 No. 1 Maret 2015. Universitas Brawijaya.

Dewo Adhi Guminto dan Maria Assumpta Evi Marlina. 2019. Dampak Kerusuhan Mako Brimob Mei 2018 Terhadap Abnormal Return Indeks LQ45 yang Terdaftar di BEI. Media Akuntansi dan Perpajakan Indonesia, Vol. 1, No. 1, September 2019 1-11 ISSN

Fahmi, Irham. 2014. Manajemen Keuangan Perusahaan dan Pasar Modal. Jakarta. Mitra Wacana Media

Hartono, Jogiyanto. 2017. Teori Portofolio dan Analisis Investasi. Yogyakarta. BPFE-Yogyakarta

Hartono, Jogiyanto. 2018. Studi Peristiwa Menguji Reaksi Pasar Modal Akibat Suatu Peristiwa. Yogyakarta. BPFEYogyakarta

Januar Romadhona. 2019. Pengaruh Peristiwa Bom Bunuh Diri 13 Mei 2018 Di Surabaya Terhadap Abnormal Return dan Volume Perdagangan Perusahaan LQ45 Yang Terdaftar di BEI. E-JRA Vol. 08 No. 03 Agustus 2019 Fakultas Ekonomi dan Bisnis Universitas Islam Malang.

Junior Meigel Rundengan, Marjam Mangantar, Joubert B. Maramis. Reaksi Pasar Atas Pelantikan Sri Mulyani Sebagai Menteri Keuangan Pada 27 Juli 2016 (Studi Pada Saham LQ45) The Market Reaction To The Inauguration Of Sri Mulyani As Finance Minister On 27 July 2016 (Study On LQ45 Stock). Jurnal EMBA Vol.5 No.2 September 
2017, Hal.2731-2741. Universitas Sam Ratulangi.

Mutmainna Indah Andriyani Dewi, Moh. Amin, M.Cholid Mawardi. 2018. Reaksi Investor Dalam Pasar Modal Terhadap Peristiwa Aksi Bela Islam 4 November 2016 di Jakarta (Studi Event Pada Perusahaan yang Terdaftar di LQ-45 di Bursa Efek Indonesia). E-JRA Vol. 07 No. 07 Agustus 2018 Fakultas Ekonomi dan Bisnis Universitas Islam Malang

Ni Komang Diantriasih, I Gusti Ayu Purnamawati, Made Arie Wahyuni. 2018. Analisis Komparatif Abnormal Return, Security Return Variability dan Trading Volume Activity Sebelum dan Setelah Pilkada Serentak Tahun 2018. 2018. JIMAT (Jurnal Ilmiah Mahasiswa Akuntansi) Universitas Pendidikan Ganesha, Vol: 9 No: 2 Tahun 2018 eISSN: $2614-1930 . \quad$ Universitas Pendidikan Ganesha.

Ni Putu Amelia Santi Dewi, Made Arie Wahyuni, Putu Eka Dianita M. D. 2017. Pengaruh Pemilihan Gubernur DKI Tahun 2017 Terhadap Abnormal Return dan Volume Perdagangan Saham LQ45 Di BEI. e-Journal S1 Ak Pendidikan Universitas Pendidikan Ganesha Jurusan Akuntansi Program S1 (Vol: 8 No: 2 Tahun 2017). Universitas Pendidikan Ganesha.

Nurhaeni, Nunung ST. Dampak Pemilihan Umum Legislatif Indonesia Tahun 2009 Terhadap Abnormal Return dan Aktivitas Volume Perdagangan Saham di BEI

(Uji Kasus Pada Saham yang Terdaftar Dalam Kelompok Perusahaan LQ 45).

Tesis. Program Studi Magister Manajemen Universitas Diponegoro
Putu Aris Kusdarmawan dan Nyoman Abundanti. 2018. Analisis Abnormal Return Saham Sebelum dan Sesudah Reverse Stock Split pada Perusahaan di BEI Periode 2011-2015.E-Jurnal Manajemen Unud, Vol. 7, No. 7, 2018: 3827-3855

Rahyuda, Ketut. 2017. Metode Penelitian Binsis Edisi Revisi 2017. Denpasar. Udayana University Press .

Setya Kristiyanto, Sri Hermuningsih. 2018. Pengaruh Peristiwa Bom Thamrin Terhadap Return Saham dan Trading Volume Activity Pada Perusahaan LQ45 yang Terdaftar di Bursa Efek Indonesia. Jurnal Manajemen Dewantara Vol 2 No 1 (2018): 55 - 67

Sugiyono. Metode Penelitian Kuantitatif Kualitatif dan R\&D. 2017. Bandung. Penerbit Alfabeta.

Sugiyono. Metode Penelitian Kuantitatif Kualitatif dan R\&D. 2019. Bandung. Penerbit Alfabeta.

Sujarweni, V Wiratma. Kupas Tuntas Penelitian Akuntansi dengan SPSS. 2016. Yogyakarta. Pustaka Baru Press.

Tri Yuniati. 2017. Analisis Abnormal Return Dan Trading Volume Activity Saham LQ45 Pada Seputar Peristiwa Pengumuman Kebijakan Pengampunan Pajak (Tax Amnesty). Skripsi. Fakultas Ekonomi dan Bisnis Universitas Lampung

Undang-undang Nomor 8 Tahun 1995 tentang Pasar Modal

Wiwik Tiswiyanti, Asrini. 2015. Reaksi Investor Atas Pengumuman Kenaikan Harga BBM Terhadap Abnormal Return, Security Return Variability Dan 
WICAKSANA, Jurnal Lingkungan \& Pembangunan, Maret 2020

ISSN: 2597-7555

E-ISSN: 2598-987

https://ejournal.warmadewa.ac.id/index.php/wicaksana

Trading Volume Activity Saham Perusahaan Transportasi Di Bursa Efek Indonesia Tahun 2014. Jurnal Studi Manajemen Dan Bisnis Vol 2 No. 2 Tahun 2015. Universitas Sumatera Utara.

Yusnia Febrina Sari. 2016. Pengaruh Perombakan (Reshuffle) Kabinet Kerja Terhadap Reaksi Pasar Modal Indonesia (Event Study Pada Saham LQ45 yang Terdaftar di Bursa Efek Indonesia). Skripsi. Fakultas Ekonomi dan Bisnis Universitas Lampung. www.idx.co.id

www.cnnindonesia.com/nasional/2019050808 3244-32-392910/jalan-panjang-pemiluserentak-2019-yang-telan-ratusannyawa

www.bbc.com/indonesia/indonesia-47879833

www.jawapos.com/ekonomi/finance/18/04/20 19/pemilu-berjalan-lancar-182-sahamlangsung-menguat-di-sesi-perdagangan-pagi/ 